\title{
Pengendalian Dokumen Impor Untuk Mencegah Keterlambatan Penyelesaian Proyek Kapal di PT PAL Indonesia (Persero) Surabaya
}

\author{
RAJ Susilo ${ }^{a^{*}}$, Mashudi Rofiq ${ }^{b}$, Dimas Pratamac Prapti Utami ${ }^{d}$ \\ abcd Politeknik Ilmu Pelayaran Semarang \\ a*Email: ray.susilo@yahoo.com
}

\begin{abstract}
ABSTRAK
Pertahanan nasional khusus matra laut mengemban tugas menegakkan kedaulatan dan menjaga keutuhan wilayah NKRI. Sehingga dibutuhkan dalam jumlah besar kapal perang Republik Indonesia, yang pengadaannya melalui proyek dalam negeri maupun luar negeri. Khusus pada proyek pengadaan kapal luar negeri, pemerintah melalui Undang-Undang Nomor 16 Tahun 2012 tentang Industri Pertahanan berupaya untuk memaksimalkan penggunaan produksi dalam negeri untuk memberdayakan industri pertahanan dalam negeri serta meningkatkan kesejahteraan perekonomian nasional. Penelitian ini berupaya untuk mengkaji tentang proses penanganan dokumen impor yang ada di PT. PAL Indonesia - Surabaya, agar penyelesaian proyek yang ada di PT. PAL Indonesia - Surabaya tersebut tidak terkendala. Metode kualitatif deskriptif dan sampel diambil di PT. PAL Indonesia-Surabaya.

Dari hasil penelitian dapat disimpulkan bahwa PT. PAL Indonesia - Surabaya untuk menyelesaikan customs clearance-nya di daerah pabean belum optimal. Perlu adanya pengawasan agar dapat berjalan sesuai yang telah direncanakan. SP-1 yang di keluarkan Kementerian Pertahanan Republik Indonesia cukup lama penerbitannya, sehingga menimbulkan beban biaya storage dan demmurage tinggi. Untuk menghindarinya, PT. PAL Indonesia - Surabaya mengajukan persetujuan eigen losing kepada KPPBC sesuai prosedur eigen losing, meliputi jangka waktu penimbunan, dan tanggung jawab atas bea masuk serta biaya demmurage dan storage. Kesimpulannya dalam pengeluaran barang yang lama berdampak pada waktu produksi pembangunan kapal yang terhambat tidak sesuai target yang di rencanakan.
\end{abstract}

Kata Kunci: Pengendalian, Dokumen, Impor, PT PAL

\section{PENDAHULUAN}

PT. PAL Indonesia adalah perusahaan yang bergerak di bidang industri galangan kapal yang kegiatan utamanya adalah memproduksi kapal perang dan kapal niaga, memberikan jasa perbaikan dan pemeliharaan kapal, serta rekayasa umum dengan spesifikasi tertentu berdasarkan pesanan.

Untuk pembuatan kapal baru yang akan di produksi membutuhkan bahan baku yang diimpor dari luar negeri karena indutri dalam negeri belum memenuhi standar produksi perusahaan.

Impor adalah memasukkan barangbarang dari luar negeri sesuai dengan peraturan pemerintah ke dalam peredaran dalam masyarakat yang dibayar dengan valas (Amir MS, 2013:139). Penanganan dokumen impor memerlukan keterkaitan antara importir dengan perusahaan forwarder. Pihakpihak yang terkait dalam penanganan impor barang, khususnya melalui pengangkutan laut antara lain: shipper, consignee, asuransi, freight forwarder/customs clearances, bank, Bea Cukai, dan Pelindo. Pihak-pihak tersebut mempunyai peran dan tanggung jawab dalam bidangnya masing-masing tergantung pada pola hubungan yang diinginkan. Pejabat bea dan cukai diberi wewenang untuk meneliti dan menetapkan tarif nilai pabean untuk perhitungan bea masuk. Importir diminta untuk memberitahukan 
di dalam pemberitahuan impor barang (PIB) berupa jumlah, jenis dan harga barang. Besar kecilnya pungutan negara sangat bergantung terhadap nilai pabean yang diberitahukan oleh importir, setiap barang yang menjadi barang impor harus melalui sejumlah beberapa tahapan pemeriksaan sesuai penjaluran yang telah ditentukan Direktorat Jenderal Bea dan Cukai. Dengan demikian, importir juga mempunyai kendala di mana kendala tersebut muncul pada saat pergerakan barang yang tidak diikuti dengan pengurusan dokumennya tersebut. Dokumen yang tidak lengkap akan menghambat proses pengeluaran barang dari tempat lapangan penumpukan. Oleh karena itu perlu adanya pengendalian khusus terhadap dokumen yang di terima importir dan yang dikuasakan pengurusannya kepada Pengusaha Pengurusan Jasa Kepabeanan (PPJK) yang merupakan bagian dari forwarder. Tujuan dari pemindahan penguasaan tersebut untuk mempercepat pengurusan barang yang berada di dalam daerah pabean dan untuk menghindari biayabiaya berlebih akibat pengurusan customs clearance yang lama. Biaya tersebut diantaranya adalah biaya storage dan biaya demurrage yang dibebankan kepada importir di luar biaya pokok pembayaran atas barang impor, sehingga dalam proses importasi diperlukan suatu penanganan khusus.

Berdasarkan latar belakang masalah di atas, dapat diidentifikasikan masalah sebagai berikut: 1. Lamanya penyelesaian barang impor di daerah pabeanan 2. Terjadinya storage dan demurrage. 3. Dokumen yang diterima PPJK tidak lengkap. Adapun Pembatasan masalah merupakan kerangka permasalahan yang sengaja dibatasi agar tidak lepas dari pokok masalah yang utama, maka peneliti akan memfokuskan permasalahan yang berkaitan dengan upaya penanganan impor. Mengingat sangat luasnya ruang lingkup impor, maka penulis membatasi penelitian ini pada : a). Penanganan dokumen impor pada perusahaan tersebut. b). Hambatan pengurusan customs clearances oleh PPJK yang terlalu lama. Berdasarkan latar belakang masalah, identifikasi masalah dan pembatasan masalah di atas, maka masalah yang akan dibahas dalam penelitian ini adalah : 1). Bagaimanakah proses pengendalian dokumen impor material kapal di PT. PAL (Persero) Surabaya dan 2). Adakah hambatan yang dihadapi PT. PAL (Persero) Surabaya dalam pelaksanan impor material

Tujuan penelitian ini mengarah pada pelayanan yang dilakukan secara terencana dan sistematis untuk mencapai tujuan yang diinginkan, tujuan merupakan suatu faktor yang sangat penting dalam sebuah kegiatan, oleh karena itu dengan adanya tujuan, maka kegiatan dapat terlaksana dengan jelas dan terarah, sehingga diharapkan akan memperoleh keberhasilan dengan kegiatan tersebut. Adapun tujuan yang ingin dicapai dalam penelitian ini adalah : a. Untuk dapat mengetahui pengendalian dokumen impor PT. PAL (Persero) Surabaya dalam mengimpor material proyek kapal b. Untuk dapat mengetahui kendala PT. PAL (Persero) Surabaya dalam mengimpor material kapal.

Freight forwarding adalah bagian dari ilmu pengangkutan muatan atau barang secara keseluruhan yang meliputi jalur laut, darat maupun udara. Dalam hal ini fright forwarding dapat menjadi Ekspedisi Muatan Kapal Laut (EMKL). Efektifitas menggunakan jalur laut dapat mengangkut barang dengan kapasitas yang cukup besar dan harga murah. Fungsi dari freight forwarding merupakan jasa ekspedisi, jasa kepabeanan, serta pengiriman barang door to door.

Freight forwarder timbul karena adanya perkembangan perdagangan 
internasional yang dapat mempermudah dalam proses impor atau ekspor. Kesimpulannya Ilmu freight forwarder adalah suatu cabang ilmu pengetahuan tentang tata cara atau tata laksana untuk mengirim atau menerima barang sebagai perwakilan dari shipper atau consignee. Yang terkait dengan a). Muatan b). Pelabuhan c). Depo d). Trucking.

Proses custom clearance adalah penyelesaian dan pengurusan berbagai dokumen administrasi, biaya pajak dan hal terkait lainnya atau suatu barang ekspor maupun impor sampai tahap dikeluarkannya surat persetujuan untuk mengeluarkan barang yang dilakukan oleh forwarder untuk proses administrasi pengeluaran atau pengiriman barang di pelabuhan muat atau bongkar. Dalam hal menangani dan melayani penyelesaian proses custom clearance dilakukannya barang datang di pelabuhan bongkar hingga barang sampai diterima oleh consigne yang dibagi ke dalam dua kegiatan a). Sebelum barang sampai di pelabuhan freight forwarder akan menerima original Bill of Lading dari maskapai pelayaran yang hendak di ageni. Selanjutnya forwarder tersebut menerbitkan kembali Master Bill of Lading sesuai yang asli diterima, Master Bill of Lading yang diterbitkan forwarder tersebut diberikan kepada consignee untuk sebagai bukti kepemilikan barang. Berdasarkan ETA (Estimated Time Arrive) dalam Bill of Lading tersebut consignee akan mempersiapkan dokumen-dokumen yang diperlukan oleh PPJK untuk proses custom clearance ke bea cukai. Semua tanggung jawab proses custom clearance atas barang tersebut telah di kuasakan kepada PPJK yang ditandai dengan surat kuasa. b) Barang di simpan di container yard importir atau consignee memberitahukan kepada bea dan cukai atas kepemilikan barang impor yang sudah datang di pelabuhan sesuai inward manifest yang disebut Pemberitahuan Impor Barang (PIB). Bea dan cukai akan menganalisa dokumen yang di lampirkan apakah sudah sesuai dengan barang yang diimpor atau belum untuk penjaluran barang tersebut Dalam pengurusan kewajiban kepabeanan dibagi menjadi 3 jalur yaitu jalur hijau, jalur kuning, dan jalur merah. Selain 3 jalur tersebut juga terdapat jalur MITA (Mitra Utama) Prioritas dan MITA Non Prioritas. Barang dapat keluar atau tidak dari daerah pabean tergantung pada proses pengecekan dokumen dan pemeriksaan fisik, jika ditemukan ketidak cocokan dokumen atau terdapat barang yang tidak sesuai dengan dokumen yang telah diajukan, maka barang tidak diperbolehkan keluar dari daerah pabean, selanjutnya barang akan diamankan oleh pihak bea dan cukai. Dalam pengamatan peneliti bahwa lamanya waktu inap barang sejak barang keluar dari kapal pengangkut hingga barang keluar dari pelabuhan akan berpengaruh pada biaya storage dan demurrage. Dalam pengamatan lama waktu penimbunan yang ber Status barang impor maksimal 3 hari berada di pelabuhan, apabila waktu melebihi yang telah di tentukan maka barang tersebut harus dilakukan over brengen dipindahkan dari container yard ke depo berikut yang masih dalam pengawasan bea dan cukai. Sehingga dapat peneliti simpulkan bahwa secara garis besar proses alur dokumen yang menentukan dwelling time barang impor di pelabuhan adalah dalam kepengurusan dokumen tersebut mulai dari pre-clearance, proses custom clearance, dan post clearance. Preclearance adalah proses meletakkan barang di Container yard atau Tempat Penimbunan Sementara (TPS) dan persiapan dokumen yang dibutuhkan yaitu Pemberitahuan Impor Barang (PIB). Kegiatan Custom clearance merupakan proses pemeriksaan fisik 
barang pada jalur merah, dan verifikasi dokumen yang dibutuhkan oleh bea dan cukai. Setelah tahapan-tahapan pemeriksaan sudah terpenuhi, bea dan cukai mengeluarkan Surat Persetujuan Pengeluaran Barang (SPPB). Kegiatan Post-Clearance yaitu barang yang sudah memenuhi syarat diangkut menggunakan truk keluar dari tempat penimbunan untuk di proses delivery dan melakukan kewajiban pembayaran fasilitas jasa-jasa yang digunakan.

Dasar atau acuan yang berupa teoriteori atau temuan-temuan melalui hasil berbagai penelitian sebelumnya merupakan hal yang sangat perlu dan dapat dijadikan sebagai data pendukung. Dari penelitian terdahulu, peneliti tidak menemukan penelitian dengan konsep yang sama seperti konsep penelitian peneliti. Namun peneliti mengangkat beberapa penelitian sebagai referensi dalam memperkaya bahan kajian pada penelitian. Berikut merupakan beberapa penelitian terdahulu berupa beberapa jurnal atau tugas akhir terkait dengan penelitian yang dilakukan peneliti.

Tabel 1. Literatur Penelitian Terdahulu

\begin{tabular}{|c|c|c|c|}
\hline $\begin{array}{l}\text { Sumber } \\
\text { Penelitia } \\
\mathrm{n}\end{array}$ & $\begin{array}{l}\text { Variabel } \\
\text { Penelitian }\end{array}$ & $\begin{array}{l}\text { Teknik } \\
\text { Analisi } \\
\text { S }\end{array}$ & $\begin{array}{l}\text { Hasil } \\
\text { Penelitia } \\
\mathrm{n}\end{array}$ \\
\hline $\begin{array}{l}\text { Rinitami } \\
\text { Njatrija } \\
\text { ni }\end{array}$ & $\begin{array}{l}\text { Variabel } \\
\text { bebas: } \\
\text { 1.Pengurusan } \\
\text { dokumen } \\
\text { 2.Impor } \\
\text { barang } \\
\text { Variabel } \\
\text { terikat: } \\
\text { 1.Dwellingti } \\
\text { me }\end{array}$ & $\begin{array}{l}\text { Regres } \\
\text { i }\end{array}$ & $\begin{array}{l}\text { SPPB } \\
\text { dapat di } \\
\text { keluarka } \\
\mathrm{n} \text { oleh } \\
\text { Bea dan } \\
\text { Cukai } \\
\text { setelah } \\
\text { barang } \\
\text { itu } \\
\text { melalui } \\
\text { beberapa } \\
\text { tahapan } \\
\text { dari pre- } \\
\text { clearanc } \\
\text { e, } \\
\text { custom } \\
\text { clearanc } \\
\text { e dan } \\
\text { post- } \\
\text { clearanc } \\
\text { e. }\end{array}$ \\
\hline
\end{tabular}

Dari data diatas dapat peneliti simpulkan adanya suatu kesamaan tentang pembahasan custom clearence sedang perbedaan nya ada di penelitian yang dilakukannya hanya membahas tentang hambatan mekanisme dalam internal perusahaan tersebut.

\section{METODE}

Penelitian ini menggunakan desain penelitian kualitatif dengan metode deskriptif. Berdasarkan metode tersebut terdapat empat kunci utama yang perlu diperhatikan yaitu cara ilmiah, data, tujuan, dan kegunaan. Cara ilmiah merupakan kegiatan penelitian yang didasarkan pada ciri-ciri keilmuan, meliputi rasional, empiris, dan sistematis. Rasional berarti kegiatan penelitian dilakukan dengan masuk akal sehingga dapat dinalar oleh pikiran manusia.

Situasi dilapangan untuk bisa menentukan dan yang dapat ditunjuk sebagai informan pertama-tama peneliti pilih satu atau dua orang, tetapi karena dengan dua orang ini belum merasa lengkap terhadap data yang diberikan, maka peneliti mencari orang lain yang dipandang lebih tahu dan dapat melengkapi data yang diberikan oleh dua orang sebelumnya. Begitu seterusnya, sehingga jumlah sampel semakin banyak. Pertimbangan peneliti menggunakan Snowball Sampling karena peneliti belum tahu situasi objek dan siapa saja yang mengetahui serta memahami informasi objek penelitian. Sehingga peneliti menitik beratkan pada kepemilikan informasi tentang pengendalian dokumen impor material kapal. Adapun sumber data yang peneliti gunakan meliputi; 1) Data Primer dimana pengumpulan data dilakukan oleh peneliti secara langsung dari sumber pertama atau tempat penelitian dilakukan. Data yang dibutuhkan diperoleh dari responden melalui kuesioner, kelompok fokus, dan panel, atau juga data hasil wawancara peneliti dengan narasumber. Dalam 
penelitian ini, data primer diperoleh peneliti dengan melakukan observasi tidak terstruktur di mana penelitian melakukan tanpa menggunakan pedoman observasi, sehingga peneliti mengembangkan penelitiannya berdasarkan kondisi perkembangan yang terjadi di lapangan. Selain itu, peneliti melakukan wawancara terarah kepada informan yang berkompeten dibidangnya, dengan melakukan tanya jawab kepada sampel penelitian yang diteliti berupa pertanyaan menggunakan pedoman yang sudah disiapkan sebelumnya. 2) Data Sekunder, dalam penelitian ini, data sekunder diperoleh dari pengumpulan data dengan cara mempelajari dan menelaah dokumen yang berkaitan dengan proses penyelesaian dokumen kapal menggunakan sistem Inaportnet

3).Wawancara mendalam (in-depth interview), di mana peneliti terlihat langsung secara mendalam dengan kehidupan subyek yang diteliti dan tanya jawab yang dilakukan tanpa menggunakan pedoman yang disiapkan sebelumnya serta dilakukan bekali-kali.

4).Wawancara terarah (guide interview), di mana peneliti menanyakan kepada subyek yang diteliti berupa pertanyaanpertanyaan yang menggunakan pedoman yang disiapkan sebelumnya. Pewawancara terikat dengan pertanyaan yang telah disiapkan sebelumnya, disamping itu peneliti juga menggunakan metode observasi dan juga dokumentasi.

\section{HASIL DAN PEMBAHASAN} PT. PAL INDONESIA mempunyai reputasi sebagai kekuatan utama untuk pengembangan industri maritim nasional serta menjalankan dan menjaga operasi perusahaan ditengah persaingan bisnis pasar global yang penuh persaingan. Sehingga menjadi perusahaan galangan kapal dan rekayasa yang berkelas, terpercaya, dan memiliki nilai tambah bagi para pemangku kepentingan. Meningkatkan kepuasan pelanggan yang ditunjang dengan mutu produk berstandar internasional dan pengiriman produk tepat waktu, serta menciptakan perusahaan yang akuntabel dan transparan yang didukung dengan sumber daya manusia yang profesional dan berpengalaman (talent mapping), selain itu didukung dengan manajemen yang modern dan teknologi yang canggih sehingga dapat menciptakan produser kapal maupun rekayasa umum terbesar, terkemuda dan terbaik di Indonesia dengan adanya persaingan produksi kapal niaga, kapal cepat, rekayasa umum, serta pemeliharaan dan perbaikan. Meliputi:

Tabel 2. Jenis dan Jam Operasional Pemeliharaan

\begin{tabular}{|l|l|l|}
\hline No & Jenis pekerjaan & $\begin{array}{l}\text { Jam } \\
\text { operasional }\end{array}$ \\
\hline 1 & $\begin{array}{l}\text { Melaksanakan jasa } \\
\text { perawatan dan } \\
\text { perbaikan kapal } \\
\text { maupun non kapal }\end{array}$ & $\begin{array}{l}\text { Senin- } \\
\text { Jumat (9 } \\
\text { jam sehari) }\end{array}$ \\
\hline 2 & $\begin{array}{l}\text { Memproduksi } \\
\text { kapal-kapal jenis } \\
\text { niaga atau kapal } \\
\text { perang }\end{array}$ & $\begin{array}{l}\text { Senin- } \\
\text { Jumat (9 } \\
\text { jam sehari }\end{array}$ \\
\hline 3 & $\begin{array}{l}\text { Memproduksi } \\
\text { rekayasa umum } \\
\text { sesuai pemesanan } \\
\text { cutomer }\end{array}$ & $\begin{array}{l}\text { Senin- } \\
\text { Jumat } \\
\text { jam sehari }\end{array}$ \\
\hline
\end{tabular}

Tabel 3. Tupoksi unit-unit yang ada di PT.PAL

\begin{tabular}{|l|l|l|}
\hline $\mathrm{N}$ & Unit & Pekerjaan \\
\hline 1 & Bidang & $\begin{array}{l}\text { 1.Menjelaskan, } \\
\text { Divisi } \\
\text { Logistik } \\
\text { pelaksanaan strategi } \\
\text { kebijakan pada } \\
\text { perusahaan } \\
\text { 2. program kerja } \\
\text { pada pengadaan } \\
\text { barang dan jasa } \\
\text { 3. penyimpangan } \\
\text { barang atau } \\
\text { peralatan untuk } \\
\text { menunjang kegiatan }\end{array}$ \\
\hline
\end{tabular}




\begin{tabular}{|c|c|c|}
\hline & & $\begin{array}{ll}\text { produksi } & \text { dan } \\
\text { operasional } & \\
\text { perusahaan. } & \end{array}$ \\
\hline 2 & $\begin{array}{l}\text { Bidang ke } \\
\text { sekretariat }\end{array}$ & $\begin{array}{l}\text { 1. Melakukan } \\
\text { kegiatan } \\
\text { kes2.ektretariatan } \\
\text { yang meliputi } \\
\text { administrasi umum, } \\
\text { administrasi } \\
\text { personil, kerumah } \\
\text { tanggan } \\
\text { keuangan dan } \\
\text { lingkungan divisi } \\
\text { logistic } \\
\text { 2. Mengelola data } \\
\text { administrasi } \\
\text { pemeliharaan asset } \\
\text { perusahaan, fasilitas } \\
\text { dan } \\
\text { perkantoran parana } \\
\text { Divisi Logistic. }\end{array}$ \\
\hline 3 & $\begin{array}{l}\text { Departeme } \\
\mathrm{n} \text { planning } \\
\text { control }\end{array}$ & $\begin{array}{l}\text { 1. menyusun } \\
\text { strategi } \\
\text { pelaksanaan } \\
\text { kebijakan Divisi } \\
\text { Logistik, jasa dan } \\
\text { program kerja di } \\
\text { bidang } \\
\text { perencanaan dan } \\
\text { pengendalian } \\
\text { barang atau } \\
\text { peralatan yang } \\
\text { digunakan } \\
\text { 2. penegelolaan } \\
\text { database material } \\
\text { dan system } \\
\text { informasinya serta } \\
\text { seleksi / evaluasi } \\
\text { vendor / supplier } \\
\text { sesuai ketentuan } \\
\text { yang berlaku } \\
\text { 3. Merencanak } \\
\text { an, mengkoordinir } \\
\text { \& melaksanakan, } \\
\text { mengevaluasi serta } \\
\text { melakukan } \\
\text { perbaikan terhadap } \\
\text { kegiatan dalam }\end{array}$ \\
\hline
\end{tabular}

\begin{tabular}{|c|c|c|}
\hline & & $\begin{array}{lr}\text { bidang } & \text { yang } \\
\text { menjadi } & \text { tanggung } \\
\text { jawabnya. } & \end{array}$ \\
\hline 4 & $\begin{array}{l}\text { Biro } \\
\text { Rendal } \\
\text { Pengadaan } \\
\text { Material } \\
\text { \& Jasa }\end{array}$ & $\begin{array}{l}\text { 1. Membuat } \\
\text { perencanaan, } \\
\text { koordinasi dan } \\
\text { pengendalian } \\
\text { sumber daya serta } \\
\text { pekerjaan di bidang } \\
\text { perencanaan dan } \\
\text { pengendalian } \\
\text { barang dan jasa } \\
\text { untuk kebutuhan } \\
\text { proyek maupun } \\
\text { kegiatan operasional } \\
\text { perusahaan sesuai } \\
\text { kebijakan yang } \\
\text { berlaku sesuai } \\
\text { dengan program } \\
\text { kerja } \\
\text { departemennya. }\end{array}$ \\
\hline 5 & $\begin{array}{l}\text { Biro } \\
\text { sistem } \\
\text { informasi } \\
\& \\
\text { akreditasi } \\
\text { pemasok }\end{array}$ & $\begin{array}{lr}1 . & \text { Membuat } \\
\text { perencanaan, } \\
\text { koordinasi } \\
\text { penendalian } & \text { damber } \\
\text { daya dan } & \text { pekerjaan } \\
\text { di bidang } & \text { sistem } \\
\text { informasi } & \text { \& } \\
\text { akreditasi pemasok } \\
\text { sesuai } \\
\text { kebijakan } & \text { denga } \\
\text { ketentuan } & \text { yang } \\
\text { berlaku } & \text { sesuai } \\
\text { dengan } & \text { program } \\
\text { kerja Departemen. }\end{array}$ \\
\hline 6 & $\begin{array}{l}\text { Biro } \\
\text { Material } \\
\text { stok \& } \\
\text { umum }\end{array}$ & $\begin{array}{l}1 . \quad \text { Membuat } \\
\text { perencanaan, } \\
\text { koordinasi dan } \\
\text { penendalian sumber } \\
\text { daya dan pekerjaan } \\
\text { di bidang persediaan } \\
\text { material dan atau } \\
\text { peralatan untuk } \\
\text { proyek maupun } \\
\text { operasional } \\
\text { perusahaan dengan }\end{array}$ \\
\hline
\end{tabular}




\begin{tabular}{|l|l|lr|}
\hline & $\begin{array}{lr}\text { ketentuan } & \text { yang } \\
\text { berlaku } & \text { sesuai } \\
\text { dengan } & \text { program } \\
\text { kerja departemen }\end{array}$ \\
\hline
\end{tabular}

PT. PAL Indonesia (Persero), diawali dari galangan kapal yang bernama MARINA yang didirikan oleh pemerintah Belanda pada tahun 1939 pada masa pendudukan Jepang. PT. PAL Indonesia (Persero) berganti nama menjadi Kaigun SE 2124. Setelah kemerdekaan pemerintah Indonesia melakukan nasionalisasi dan mengubah namanya menjadi Penataran Angkatan Laut (PAL). Pada 15 April 1980 pemerintah mengubah status perusahaan menjadi perseroan terbatas sesuai dengan akta No. 12, yang dibuat oleh notaris Hadi Mentoro, SH. Lokasi perusahaan di ujung Surabaya, dengan kegiatan utama membangun kapal perang dan kapal niaga, memberikan jasa perbaikan dan pemeliharaan kapal, serta rekayasa umum dengan spesifikasi tertentu berdasarkan pesanan. Kapalkapal produksi PAL Indonesia telah mengarungi perairan disuluruh dunia. PT. PAL Indonesia (Persero) Surabaya beralamatkan di Ujung (BASIS TNIAL) Kel. Ujung, Kec. Semampir Surabaya. Po Box 1134 Jawa Timur 60155.

Sesuai dengan misi yang dipegang yaitu meningkatkan kepuasan pelanggan dengan mutu produk yang berstandar internasional, penyerahan produk tepat waktu, serta meningkatkan pengelolaan perusahaan yang akuntabel dan transparan, penguasaan teknologi dan rancang bangun, serta berupaya memberikan kemampuan laba dan kesejahteraan secara berkesinambungan bagi para pemegang saham, karyawan, pelanggan, mitra usaha, hal ini didukung dengan kegiatan bisnis melipiti: 1) Merancang pembangunan kapal perang dan kapal niaga, 2) Menyediakan jasa perbaikan dan pemeliharaan kapal, 3) Melakukan rekayasa umum dengan spesifikasi yang telah ditentukan berdasarkan kebutuhan customer dan 4). Kepegawaian

Pegawai pada PT. PAL Indonesia (Persero) Surabaya terdiri dari pegawai operasional dan pegawai teknik. Dimana pegawai organik adalah pegawai yang direkrut oleh perusahaan sendiri untuk memenuhi kebutuhan sumber daya manusia, di mana para pegawai tersebut meliputi a). Tenaga struktural dan pelaksana yang memiliki untuk ditempatkan pada posisi-posisi strategis di perusahaan, b). Tenaga teknik yang penempatannya sesuai bidang keahliannya agar dapat menghasilkan produk sesuai yang di rencanakan. c). Kepala Divisi Logistik: Mempunyai peran dalam penyusunan strategi, kebijakan serta program yang dimiliki oleh perusahaan, serta program kerja di bidang pengadaan barang dan jasa. Selain itu juga penyimpanan barang atau peralatan dalam rangka menunjang kegiatan produksi dan operasional perusahaan. d). Sekretariat;

Mempunyai kegiatan kesektretariatan yang meliputi administrasi umum, administrasi personil, kerumah tanggaan dan keuangan di lingkungan divisi logistik,; e). Departemen planning control bertugas menjelaskan, menyusun strategi pelaksanaan kebijakan divisi logistik serta program kerja di bidang perencanaan dan pengendalian barang/ peralatan dan jasa, serta penegelolaan database material dan system informasinya serta seleksi / evaluasi vendor / supplier sesuai ketentuan yang berlaku; f). Biro Rendal Pengadaan Material \& Jasa mempunyai tugas mengkoordinasi dan mengendalikan sumber daya dan pekerjaan di bidang perencanaan dan pengendalian barang/ peralatan dan jasa untuk kebutuhan proyek maupun operasional perusahaan. g). Biro sistem informasi \& akreditasi pemasok 
bertanggung jawab dalam melakukan koordinasi dan pengendalian sumber daya dan pekerjaan di bidang sistem informasi \& akreditasi. h). Biro Material stok \& umum bertugas bertanggung jawab dalam melakukan koordinasi dan pengendalian sumber daya dan pekerjaan di bidang persediaan barang/material dan peralatan yang dibutuhkan dalam proyek maupun operasional perusahaan

Pengendalian dokumen impor material merupakan proyek kapal di PT. PAL Indonesia (Persero) Surabaya. Pengendalian dokumen impor merupakan serangkaian proses kegiatan yang melibatkan instansi terkait, antara lain seperti forwarder, PPJK dan maskapai pelayaran untuk bekerja sama. Importir memberikan kuasanya kepada forwarder untuk mengurus barang yang berada di luar negeri hingga barang diterima dengan selamat oleh consigne si penerima barang. Di dalam melaksanakan importasi permasalahan yang timbul sangatlah kompleks. Sering dikeluhkannya oleh importir yang harus mengeluarkan biaya-biaya yang timbul karena barang belum bisa keluar dari tempat penimbunan kawasan pabean. Karena tarif biaya storage bersifat progresif maka sebagai importir harus mempercepat pengurusannya. Rangkaian kegiatan pengendalian dokumen impor material proyek kapal yang akan penulis sampaikan berkaitan dengan kelambatan dapat peneliti amati sebagai berikut: 1). Kepengurusan untuk mengeluarkan sebuah SPT di PT. PAL Indonesia (Persero) Surabaya harus deketahui dan melewati Birokrasi yang cukup rumit antara lain melalui a). Kepala Divisi Logistik; b). Sekretariat; c). Departemen planning control; d). Biro Rendal Pengadaan Material \& Jasa; e). Biro sistem informasi \& akreditasi pemasok; f). Biro Material stok \& umum; g).Biro Imex \& Claim; h). Depatemen
Material Procurement; i). Departemen Pengadaan Jasa; j). Departemen Warehousing;

Untuk pengendalian dokumen impor material proyek kapal di PT. PAL Indonesia (Persero) Surabaya melalui serangkaian proses kegiatan yang melibatkan instansi terkait, antara lain seperti forwarder, PPJK dan maskapai pelayaran untuk saling bekerja sama. Importir memberikan kuasanya kepada forwarder guna mengurus barang yang berada di luar negeri hingga barang diterima dengan selamat oleh consigne si penerima barang. Berawal dari sinilah dalam melaksanakan importasi sering timbul permasalahan yang sangat kompleks. Sering dikeluhkannya oleh importir yang harus mengeluarkan biaya-biaya yang timbul karena barang belum bisa keluar dari tempat penimbunan kawasan pabean bahkan karena tarif biaya (storage) bersifat progresif maka sebagai importir harus mempercepat kepengurusannya. Sehingga dapat peneliti simpulkan dan dimulai dari: 1. Alur Importasi

a. Importasi Biasa

Dalam pelaksanaan importasi biasa / normal harus melalui beberapa tahapan yang prosedural agar dapat cepat dan tepat sesuai perencanaan. Beberapa tahapan prosedur impor yang dilakukan adalah:

a) Importir atau eksportir diluar negeri (supplier) mengadakan suratmenyurat (corespondence) menanyakan barang yang akan dijual oleh eksportir atau eksportir menawarkan barangnya. b) Setelah eksportir mengirimkan contoh barangnya, terjadilah tawar menawar hingga timbul kesepakatan bersama mengenai: 1). Jenis barang, mutu (quality), jumlah harga satuan, harga seluruhnya, kondisi harga barang. 2).Batas waktu pengiriman (shipment), jenis pengangkut (kapal 
laut) baik langsung ataupun partshipment (berangsur) 3). Cara pembayaran (tunai/ mengangsur/ consinyasi). 4).Jenis $1 / \mathrm{c}$ (irrevocable, transferable, revocable), tanpa 1/c. 5).Insurance ditutup di dalam/luar negeri.

b) Maka dibuat perjanjian jual beli antara kedua belah pihak (sales contract).

c) Dikirimlah "proforma invoice" oleh supplier kepada importir.

d) Dengan bekas sales contract \& proforma invoice tersebut importir dapat mengajukan permintaan pembukaan L/C ke bank devisa.

e) Setelah dicek oleh bank devisa dan setoran L/C serta biaya lainnya terpenuhi (antara 0\% - 100\%) dalam waktu paling lambat 7 hari setelah pembukaan L/C.

f) 1/c diterima kepada advising bank di luar negeri, dan diteruskan kepada eksportir (supplier)

g) dengan mengacu pada syarat-syarat dalam $1 / \mathrm{c}$ tersebut, supplier (eksportir) menyiapkan barang 7 dokumen, dikirimkan langsung /lewat forwarder ke perusahaan pelayaran diluar Negara.

h) Eksportir memberikan wesel/ bill of exchange, dokumen impor (original invoice, packing list, $\mathrm{B} / \mathrm{L}$ (awb), COO, COA, dan sebagainya kepada negotiating bank.

i) Eksportir menerima pembayaran wesel/bill of exchange dari negotiating bank sesuai persyaratan pada L/C.

j) Selanjutnya bank mengirim dokumen yang diperlukan untuk proses impor dan wesel opening bank.

k) Opening bank membayar kepada negotitating bank sesuai jumlah yang tertera pada wesel.

1) Opening bank (bank devisa di dalam negeri) dengan nota disposisi memberitahuakan / memberikan semua dokumen yang diperlukan untuk proses impor kepada importir.

m) Importir membuat PIB dan membayar semua bea yang harus dibayar (BM,PPN,Pph) serta pembayaran lainnya (SSBC, SSP (PPN), SSP.

n) Importir membawa dokumendokumen impor dan paling sedikit 3 lembar PIB yang sudah dicetak ke bea dan cukai untuk diproses dokumennya (mendapat nopen/nomor pendaftaran), penetapan jalur merah/hijau, serta meminta SPPB (Surat Persetujuan Pengeluaran Barang).

o) Importir menukarkan $\mathrm{B} / \mathrm{L}$ asli ke perusahaan pelayaran/agen untuk mendapatkan D/O.

p) Importir membayar warkat dana sekaligus mengajukan behandle peti kemas ke UPTK.

Berdasarkan pengamatan dan penelitian secara langsung maka penulis temukan beberapa hambatan yang timbul dalam permasalahan importasi didalam kegiatan pengendalian dokumen impor material proyek kapal di PT. PAL Indonesia (Persero) Surabaya.

Barang yang diimpor oleh KEMENHAN RI untuk keperluan pertahanan maka seluruh biaya pajak dibebaskan. Akan tetapi barang impor tersebut terkena jalur merah karena sudah di bebaskan biaya-biaya pajak atas barang tersebut.

Pengurusan custom clearance belum berjalan secara maksimal dikarenakan dokumen yang diterima tidak lengkap.

Khusus Barang pola FCL yang di timbun ditempat penimbunan kawasan pabean yang terlalu lama menyebabkan biaya-biaya storage dan demurrage akan semakin bertambah sesuai tarif yang berlaku.

\section{SIMPULAN}

Berdasarkan uraian dan pembahasan yang telah dikemukakan 
pada bab sebelumnya mengenai Pengendalian Dokumen Impor Material Proyek Kapal di PT. PAL Indonesia (Persero) Surabaya, maka dapat diambil kesimpulan bahwa:1). PPJK yang telah di tunjuk oleh PT PAL Indonesia untuk menyelesaikan customs clearance di daerah pabean belum optimal. Perlu adanya pengawasan agar dapat berjalan sesuai yang telah direncanakan. 2). Surat Perintah 1 (SP1) yang di keluarkan dari Kementerian Pertahanan cukup lama penerbitannya. Sehingga barang yang sudah terlalu lama di timbun di daerah pabean menimbulkan beban biaya storage dan demmurage yang tinggi, untuk menghindarinya PT. PAL mengajukan eigen losing kepada KPPBC. Dalam mengajukannya harus terpenuhi syaratsyarat untuk eigen losing, jangka waktu penimbunan, dan tanggung jawab atas bea masuk serta prosedur untuk mendapatkan persetujuan eigen losing. Akan tetapi Penolakan atau persetujuan eigen losing merupakan kebijakan Kepala Kantor, jadi permohonan eigen losing tidak selalu dapat disetujui. 3). Selain biaya demmurage dan storage, Dalam pengeluaran barang yang lama juga berdampak pada waktu produksi pembangunan kapal yang terhambat tidak sesuai target yang di rencanakan.

\section{DAFTAR PUSTAKA}

Anonim. (2011). Industri Galangan Kapal Nasional Sulit Bersaing. Jakarta: Majalah Industri Maritim Edisi Ketiga November-Desember 2011. Tandiele,

Asia Tenggara. (2012).
http://id.wikipedia.org, diakses pada tanggal 18 Februari 2012.

Badan Kebijakan Fiskal. Kementrian Koordinator Bidang Perekonomian. (2011). Masterplan Percepatan dan Perluasan Pembangunan Ekonomi Indonesia. Jakarta: Kementrian Koordinator Bidang Perekonomian.
Dita Ulisanti, FISIP UI, 2012103 Universitas Universitas Universitas Indonesia iversitas Indonesia Indonesia donesia Memperkuat Industri Perkapalan. (2008). http://www.bumn.go.id, diakses pada tanggal 18 Februari 2012.

Departement Dukungan Divisi Kapal Perang. Metode dan pengertian Shiplift PT. PAL Indonesia (persero). Diterbitkan 30 Maret 2006. PT. PAL Indonesia: nomor 134506

Direktorat Pembangunan Kapal. Petunjuk Organisasi Divisi Kapal Perang. Diterbitkan 17 Juli 2017. PT. PAL Indonesia: nomor 234003.

Ernawati. (2010). Analisis Kebijakan Bea Masuk Ditanggung Pemerintah Atas Impor Barang dan Bahan Guna Pembuatan Peralatan Telekomunikasi (Studi pada PT X). Skripsi Fakultas Ilmu Sosial dan Ilmu Politik Universitas Indonesia.

Faradila, Noviana. 2016. Laporan Praktek Kerja Lapangan Industri PT. PAL Indonesia (Persero). Universitas Muhammadiyah Malang: Jurusan Teknik Industri.

Firmansyah, Agung. (2008). Analisis Aspek Pajak Pertambahan Nilai (PPN) Atas Transaksi Pengadaan Kapal Laut (Vessel) Dalam Industri Pelayaran. Skripsi Fakultas Ilmu Sosial dan Ilmu Politik Universitas Indonesia. Tidak diterbitkan.

Hamdani. (2007). Seluk Beluk Perdagangan Ekspor Impor. Jakarta: Bushindo. INSA. (2011). Implementasi Asas Cabotage di Indonesia. Jakarta: DPP INSA. dan Penyebaran Pengetahuan Perpajakan (YP4).

Idris Hari Sikumbang. (2010). Indonesian Cabotage Advocation Forum Overview. 
http://iluni.org, diakses pada tanggal 5 Februari 2012.

Industri Galangan Butuh Insentif. (2012). http://koran-jakarta.com, diakses pada tanggal 5 Februari 2012.

Jupriansyah, Endy. (2010). Implementasi Kebijakan Penurunan Tarif Bea Masuk Gula Sebagai Salah Satu Instrumen Stabilisasi Persediaan (Stok) Gula Domestik Periode Oktober 2009 s/d Desember 2009. Skripsi Fakultas Ilmu Sosial dan Ilmu Politik Universitas Indonesia.

Johar, Benny. (2011). Kebijakan Insentif Fiskal Bagi Industri Perkapalan Dalam Rangka Meningkatkan Daya Saing Industri Perkapalan Dalam Negeri. Skripsi Fakultas Ilmu Sosial dan Ilmu Politik Universitas Indonesia.

Muhdori. (2007). Kemampuan Industri Perkapalan Nasional Dalam Menghadapi Persaingan Global. http://www.kemenperin.go.id, diakses pada tanggal 10 Februari 2012.

Marsuni, Lauddin. (2006). Hukum dan Kebijakan Perpajakan di Indonesia. Yogyakarta: UII Press.

MS, Amir. (1999). Ekspor Impor Teori dan 101 Universitas Universitas Universitas Indonesia iversitas Indonesia Indonesia

Peluang Industri Perkapalan Indonesia. (2010). http://id.voi.co.id, diakses pada tanggal 5 Februari 2012.

Slamet, Cahyo. 2012. Peluncuran Dan Docking Metode Naik Turun Kapal Boat Darat Ke Air Dan Sebaliknya. Indonesia: Boat Indonesia Co.

Sood, Muhammad. (2010). Penerapan Tarif Impor Berdasarkan Ketentuan GATTWTO, AFTA dan Perundang-undangan Indonesia. Peraturan Peraturan
Peraturan Perundang-Undangan raturan Perundang-Undangan Perundang-Undangan rundangUndangan Republik Indonesia, Instruksi Presiden Nomor 5 Tahun 2005 tentang Pemberdayaan Industri Pelayaran Nasional.

Tino Oktaviano. (2011). Membangun Industri Maritim. http://www.investor.co.id, diakses pada tanggal 9 Februari 2012.

Yan Sebarang. (2011). Membangunkan Raksasa Tidur. Jakarta: Majalah Industri Maritim Edisi Ketiga November-Desember 2011. Redaksi Indonesia Maritime Institute. "Asas Cabotage" Pelayaran Nasional Tersenyum..?. http://indomaritimeinstitute.org/ $? \mathrm{p}=1525$. Diunduh 6 Desember 2011, Pukul 12.57 WIB.

\begin{tabular}{llr} 
& & \multicolumn{2}{c}{ Undang-Undang } \\
Nomor 10 & Tahun & 1995 \\
sebagaimana & telah & diubah \\
dengan Undang-Undang & Nomor \\
17 Tahun 2006 tentang
\end{tabular}
Kepabeanan.

No. 17 Tahun 2008 tentang Pelayaran.

Menteri Keuangan Nomor 132/PMK.010/2005 tentang Program Harmonisasi Tarif Bea Masuk 2005-2010 Tahap Kedua.

Menteri Keuangan Nomor 241/PMK.011/2010 tentang Perubahan Keempat Atas Peraturan Menteri Keuangan Nomor 110/PMK.010/2006 tentang Penetapan Sistem Klasifikasi Barang dan Pembebanan Tarif Bea Masuk Atas Barang Impor.

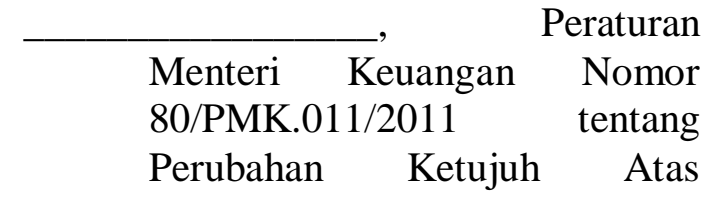


Peraturan Menteri Keuangan

Nomor 110/PMK.010/2006

tentang Penetapan Sistem

Klasifikasi Barang dan

Pembebanan Tarif Bea Masuk

Atas Barang Impor.

Peraturan

Menteri Keuangan Nomor

142/PMK.04/2011 tentang

Impor Sementara. Media Cetak

dia Cetak dan tak dan

Elektronik: an Elektronik:

Elektronik: ektronik:

Kementrian Keuangan. (2010).

Kebijakan Tarif Bea Masuk.

Jakarta: Badan Kebijakan Fiskal.

Kementrian Keuangan. (2011).

Keterangan Pers: Penetapan

Tarif Bea Masuk Umum (MFN)

Tahun $2011 \quad$ Berdasarkan

Peraturan Menteri Keuangan

Nomor 80/PMK.011/2011.

Jakarta: 